IS-5035

UC 102

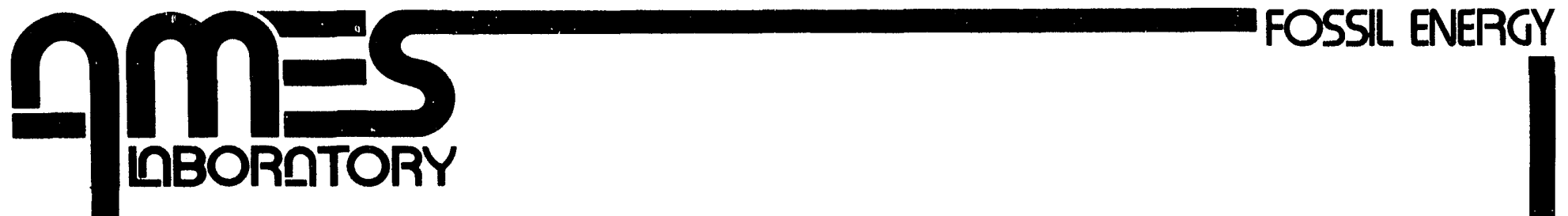

\title{
PREDICTION AND EVALUATION OF COAL CLEANABILITY
}

FOSSIL ENERGY QUARTERLY REPORT

January 1, 1990 - March 31, 1990

W. E. Straszheim, R. Markuszewski, and G. M. Oren

Ames Laboratory

lowa State University

Ames, lowa 50011-3020

Date Transmitted: April, 1990

Prepared for:

Pittsburgh Energy Technology Center

Pittsburgh, Pennsylvania

Operated for the U. S. Department of Energy under contract No. W-7405-ENG-82 


\section{DISCLAIMER}

This report was prepared as an account of work sponsored by an agency of the United States Government. Neither the United States Government nor any agency thereof, nor any of their employees, makes any warranty, expross or implied, or assumes any legal liability or responsibility for the accuracy, completeness or usefulness of any information, apparatus, product, or process disclosed, or represents that its use would not infringe privately owned rights. Reference herein to any specific commercial product, process, or service by trade name, trademark, manufacturer, or otherwise, does not necessarily constitute or imply its endorsement, recommendation, or favoring by the United States Government or any agency thereof. The views and opinions of authors expressed herein do not necessarily state or reflect those of the United States Government or any agency thereof.

Printed in the United States of America

Available from

National Technical Information Service

U.S. Department of Commerce

5265 Port Royal Road

Springfield, VA 22161 
IS --5035

DE92 002581

PREDICTION AND EVALUATION OF COAL CLEANABILITY

Fossil Energy Quarterly Report

January 1, 1990 - March 31, 1990

W. E. Straszheim, R. Markuszewski, and G. M. Oren

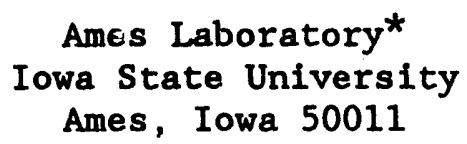

Date Transmitted: April 1990

Prepared for: Pittsburgh Energy Technology Center Pittsburgh, Pennsylvania

Project Monitor: J. Balzarini

\footnotetext{
*Operated for the U. S. Department of Energy

by Iowa State University

under Contract No. W-7405-Eng-82.
}

DISTRIBUTION OF THIS, DOCUMENT IS UMUIMITEQ Ch 


\title{
PREDICTION AND EVALUATION OF COAL CLEANABILITY
}

Fossil Energy Quarterly Report, IS-5035

January 1, 1990 - March 31, 1990

W. E. Straszheim, R. Markuszewski, and G. M. Oren Ames Laboratory

Iowa State University

\begin{abstract}
Samples of 200-mesh Upper Freeport, Illinois No. 6, and Pittsburgh No. 8 coals being used in the DOE-sponsored development of advanced surfacebased cleaning technologies at the University of Pittsburgh, the University of California at Berkeley, and at the Ames Laboratory were characterized to predict their cleanability. Scanning electron microscope-based automated image analysis (SEM-AIA) was used to measure particle size, identity, and association with the organic matrix for the mineral particles in these coals. The coal-mineral association was expressed as a function of particle mineral content and as a function of the fraction of particle surface covered by mineral matter. The results were used to predict the cleanability of these coals for density-based and surface-based cleaning processes, respectively.

Significant differences were found for the cleanabilities of the three coals, as well as for the potential for reduction in individual minerals within the same coal. The sample of Pittsburgh No. 8 coal from the University of Pittsburgh was significantly finer than the corresponding sample from Berkeley, the difference apparently being due to a different grinding method. The finer size distribution led to significantly less association of the minerals with this coal, thus making the coal apparently more cleanable.

For the three coals from Berkeley, the predicted cleanability for density-based processes was best for the Upper Freeport coal, followed by that of the Illinois No. 6 and then the Pittsburgh No. 8 coals. From our predictions based on SEM-AIA results, about 75-80\% of all minerals and 85$90 \%$ of the pyrite could be removed while maintaining $90 \%$ recovery of the coal. For surface-based cleaning, the predicted cleanability followed the same order, although there was less noticeable difference between the Illinois No. 6 and Pittsburgh No. 8 coals. Only $55-70 \%$ of the mineral matter and 55-75\% of the pyrite were predicted to be removable with $90 \%$ recovery of the coal. That is, about 15-20\% less mineral matter should be removable for a given level of recovery for surface-based methods for these coals.
\end{abstract}


PREDICTION AND EVALUATION OF COAL CLEANABILITY

W. E. Straszheim, R. Markuszewski, and G. M. Oren

\section{INTRODUCTION}

The objective of this project is to develop and apply scanning electron microscope-based automated image analysis (SEM-AIA) techniques to the prediction and evaluation of coal cleanability. Conventional washability determinations are difficult and/or unreliable at the fine particle sizes necessary for advanced, deep cleaning processes. However, SEM techniques can easily analyze particles only a few micrometers in diameter. Since the behavior of a particle in a cleaning circuit depends to a large degree on the distribution and amount of coal and mineral matter within it, SEM-AIA techniques are being applied to the measurement of coal-mineral association for thousands of particles with the results being used to predict the cleanability of the coal.

Techniques developed at the Ames Laboratory [1,2] are currently used to measure the coal-mineral association in terms of the weight fraction of coal and minerals present in the particles and in terms of the fractional coverage of particle surface by coal and minerals. The first format is suited to predicting cleanability for density-based processes, since the mineral content of the particle can be easily related to particle density. The second format is suited to predicting cleanability for surface-based processes, such as froth flotation or oil agglomeration, where the fractional amount of coal on the surface of a particle is related to the likelihood that a particle will appear in the clean coal stream.

Such association analyses can also be applied to products from grinding and cleaning processes. Results can be used to evaluate the effectiveness of comminution processes in liberating mineral matter and to evaluate the effectiveness of cleaning processes in removing mineral matter.

Current work focuses on characterizing the mineral matter in a suite of three coals being used in the DOE-sponsored development of advanced surfacebased cleaning technologies at the University of Pittsburgh (UP), at the University of California at Berkeley (UCB), and at the Ames Laboratory (Ames). These three institutions are coordinating their research to the extent that they will be working with representative samples of the same 
coals as provided through Praxis Engineers of Milpitas, California. SEM-AIA results for 200 -mesh samples of the raw coals will be used to provide fundamental information on the association of minerals with the coal matrix for these samples and to predict their cleanability. Analyses of various size fractions (e.g., 28- and 200-mesh) will be used to quantitatively measure the progressive liberation of mineral matter from coal with decreasing particle size. Time permitting, sets of samples representing different grinding procedures will also be analyzed to compare the effectiviness of liberation for different methods of grinding. Finally, selected samples of cleaned coals will be analyzed to evaluate the effectivenuss of cleaning processes at removing mineral matter as a function of the degree of coal-mineral association.

\section{PROGRESS}

Currently, samples of the three coals at two sizes (28 mesh by 0 and 200 mesh by 0 ) have been received from UP and from UCB and prepared for analysis. Ames Laboratory has received shipments of coarser samples of the coals which are currently being prepared. Analyses of the samples are presented in Table 1, taken from information provided through the Pittsburgh Energy Technology Center. Pyrite content ranges from about $1.4 \%$ in the Upper Freeport coal to nearly 3\% in the Illinois No. 6 and Pittsburgh No. 8 coals. Ash content is about $12 \%$ in the Upper Freeport and Pittsburgh No. 8 coals and about $16 \%$ in the Illinois No. 6 coal. Mineral matter calculated by using a mudified Parr formula [3] ranged from about $14 \%$ in the Upper Freeport and Pittsburgh No. 8 coals to about 19\% in the Illinois No. 6 coal.

Samples were prepared and analyzed by using procedures described previously $[1,4]$. Briefly, about $2 \mathrm{~g}$ of coal were embedded in molten carnauba wax, the pellet was sectioned and polished to expose cross sections through coal and mineral particles, and the surfaces were coated with carbon for SEM examination.

SEM-AIA was used to characterize each sample for particle size, mineral identity, and coal-mineral association. Particles were located and sized using a backscattered electron image. Mineral particles were identified from the relative abundance of the elements present in their $x$-ray spectra. Particle area and perimeter were recorded, with perimeter subdivided into the amounts adjoining coal, mineral matter, and mounting material. From the 
Table 1. Characteristics of the coals examined. All results are reported as $\%$ of dry coal.

\begin{tabular}{|c|c|c|c|}
\hline & $\begin{array}{c}\text { Upper } \\
\text { Freeport }\end{array}$ & $\begin{array}{l}\text { Iilinois } \\
\text { No. } 6\end{array}$ & $\begin{array}{c}\text { Pittsburgh } \\
\text { No. } 8\end{array}$ \\
\hline $\begin{array}{l}\text { Pyritic Sulfur } \\
\text { Total Sulfur } \\
\text { Ash } \\
\text { Mineral Mattera }\end{array}$ & $\begin{array}{l}1.42 \\
2.35 \\
11.9 \\
14.1\end{array}$ & $\begin{array}{l}2.68 \\
4.46 \\
15.9 \\
19.2\end{array}$ & $\begin{array}{l}2.78 \\
3.90 \\
11.9 \\
14.8\end{array}$ \\
\hline
\end{tabular}

aCalculated using a modified Parr formula [ref 3].

area of the constituents of a composite coal-mineral particle, its mineral content was determined. From perimeter data, the fraction of the perimeter occupied by coal and minerals was determined and expressed simply as the fractional mineral coverage of the particle surface. Several thousand particles were analyzed for each sample to achieve reproducibility. Generally, analyses required about 15 hours of instrument time per sample.

Analyses of all three coals (i.e., the Pittsburgh No. 8, Upper Freeport, and Illinois No. 6 samples) from UCB and of the sample of Pittsburgh No. 8 coal from UP were completed this quarter. Mineral particle size distributions for the four samples are presented in Figures $1 \mathrm{a}-\mathrm{d}$ and coal-mineral association results are presented in Figures 2-5. In addition, the coal-mineral association results were used to predict coal recovery versus expected mineral rejection. Predictions were made by assuming collection of all particles above various minimum qualities (i.e., mineral content or coal coverage of the surface). These results are presented as Figures $6 \mathrm{a}-\mathrm{d}$.

\section{Size Distributions}

Size distributions of the four coals analyzed to date are shown in Figures la-d. These results indicate that pyrite is the dominant mineral in each coal, and that it is also the coarsest mineral. In all threc samples from UCB, the pyrite shows a bimodal size distribution. The pyrite smaller than $4 \mu \mathrm{m}$ exists quite likely as finely disseminated single crystals of pyrite. The material larger than $7 \mu \mathrm{m}$ likely represents framboids and other massive forms and/or assemblages of pyrite. 

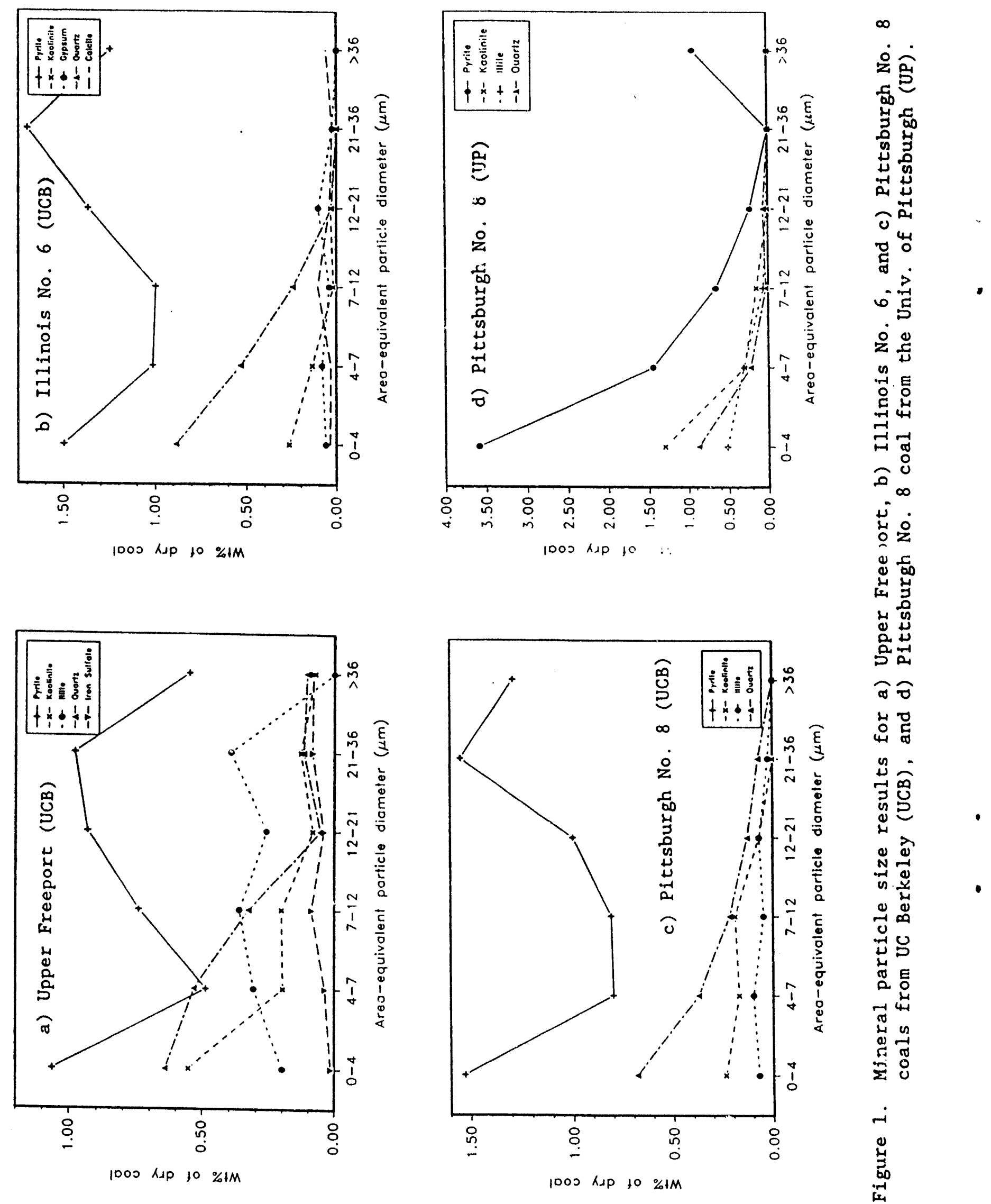
The remaining mineral matter was found to be quartz, kaolinite, and 1llite. Some gypsum was found in the Illinois No. $6 \mathrm{coal}$, and some iron sulfate was found in the Upper Freeport coal. These minerals varied in their size distributions but were un:formly finer than the pyrite. Some rather coarse 1llite was found in the Upper Freeport coal.

Size distributions of the mineral matter in the Pittsburgh No. 8 sample from UP (Figure 1d) show the sample to be much more finely ground. Since researchers at UCB and UP used different grinding methods to produce their 200-mesh samples (rod mills and ball mills, respectively), those different methods have definitely manifested themselves in different size distributions. The pyrite in the Pittsburgh No. 8 sample from UP still displays a bimodal size distribution; however, there is a large amount of uncertainty in the exact shape of the distribution since few large particles were encountered. If the overall particle size distributions (coal and embedded mineral matter) were similar for the Pittsburgh No. 8 samples from UCB and UP, then the sample from UP would be deemed much less cleanable. However, the coal particles are also much smaller in the sample from UP. Therefore, association analyses are necessary to determine which source has prepared the more cleanable sample.

\section{Coal-mineral association results}

Coal-mineral association results are presented in Figures 2-5, with one sample per figure. Each figure contains results expressed both in terms of particle mineral content (sections $a$ and $b$ ) and coverage of the particle surface by mineral matter (sections $c$ and $d$ ). The figures also present association between coal and mineral matter without making distinctions according to mineral identity (sections a and $c$ ), and with the mineral matter portion expanded to show the distribution of the minerals by type (sections $b$ and $d$ ).

In all figures, the mineral matter appears to be reasonably well liberated when coal-mineral association is expressed in terms of particle mineral content. A large fraction of the mineral matter was found in mineral-rich particles which are represented on the right-hand side of the figures (see section a), rather than in middlings particles of lower mineral content which would contribute to the center sections of the figures. The liberation is seen to be best for the sample of pittshurgh No. 8 coul from 

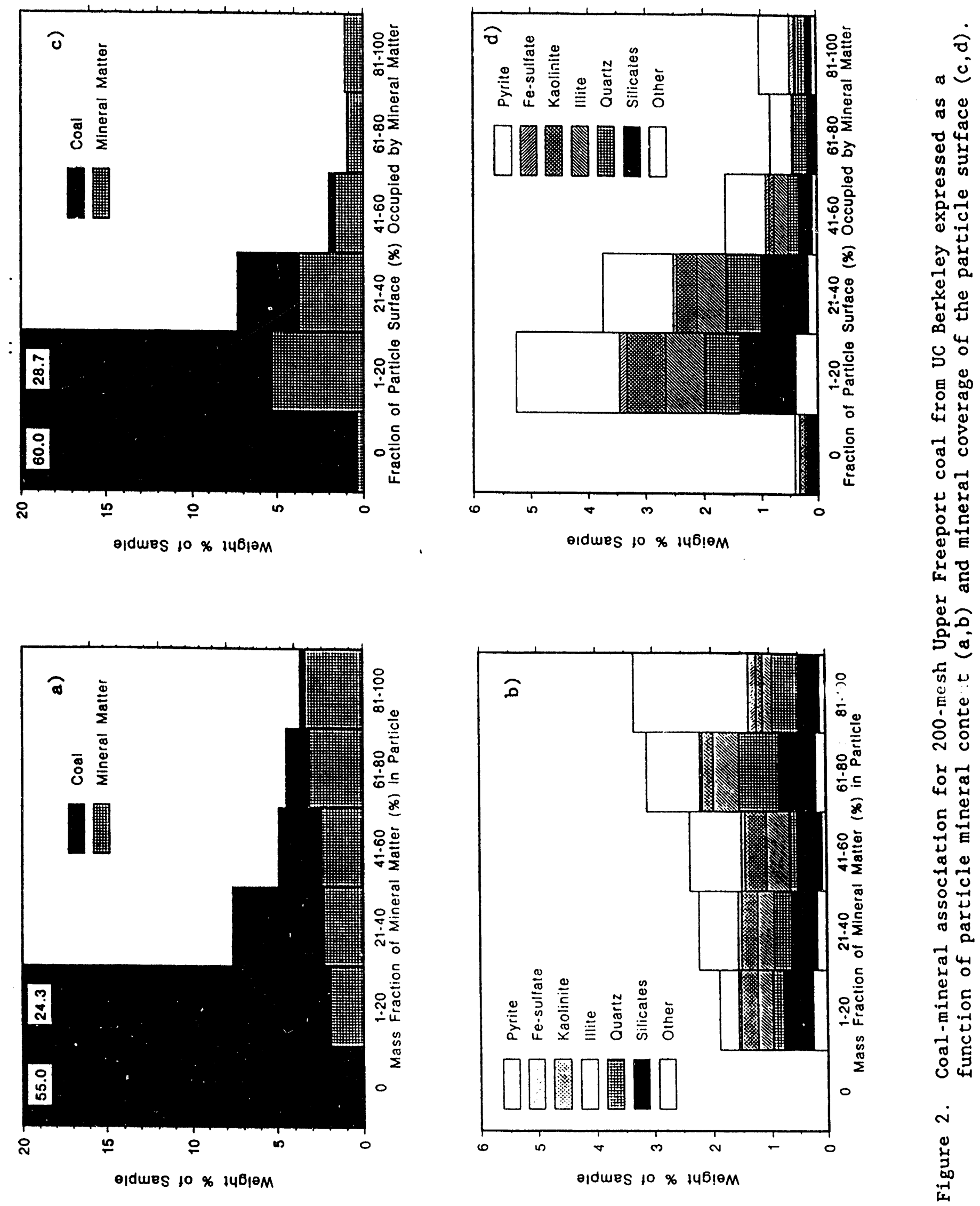

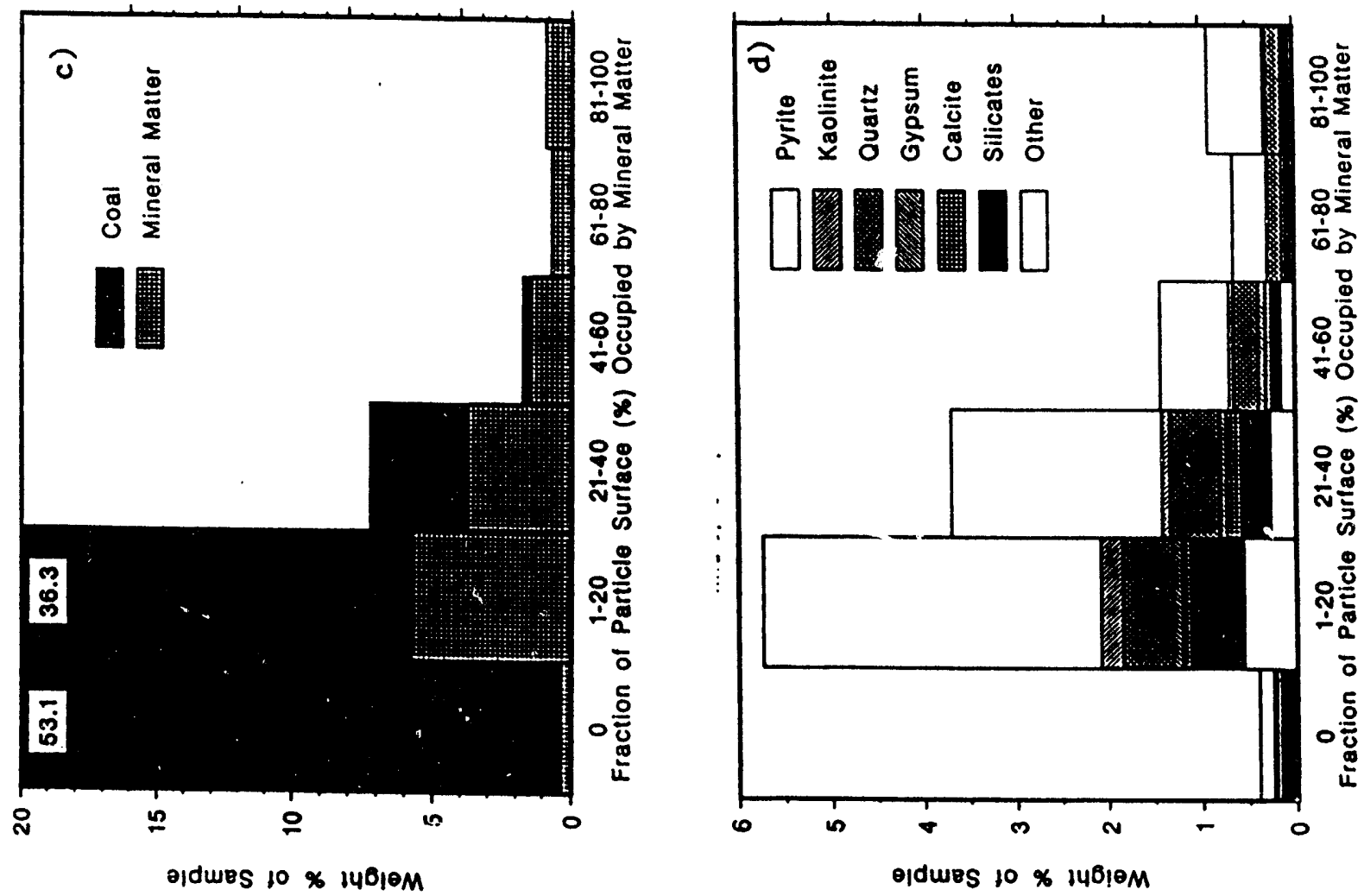

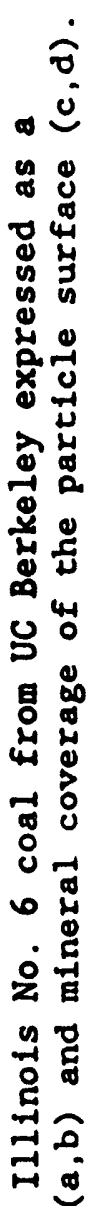
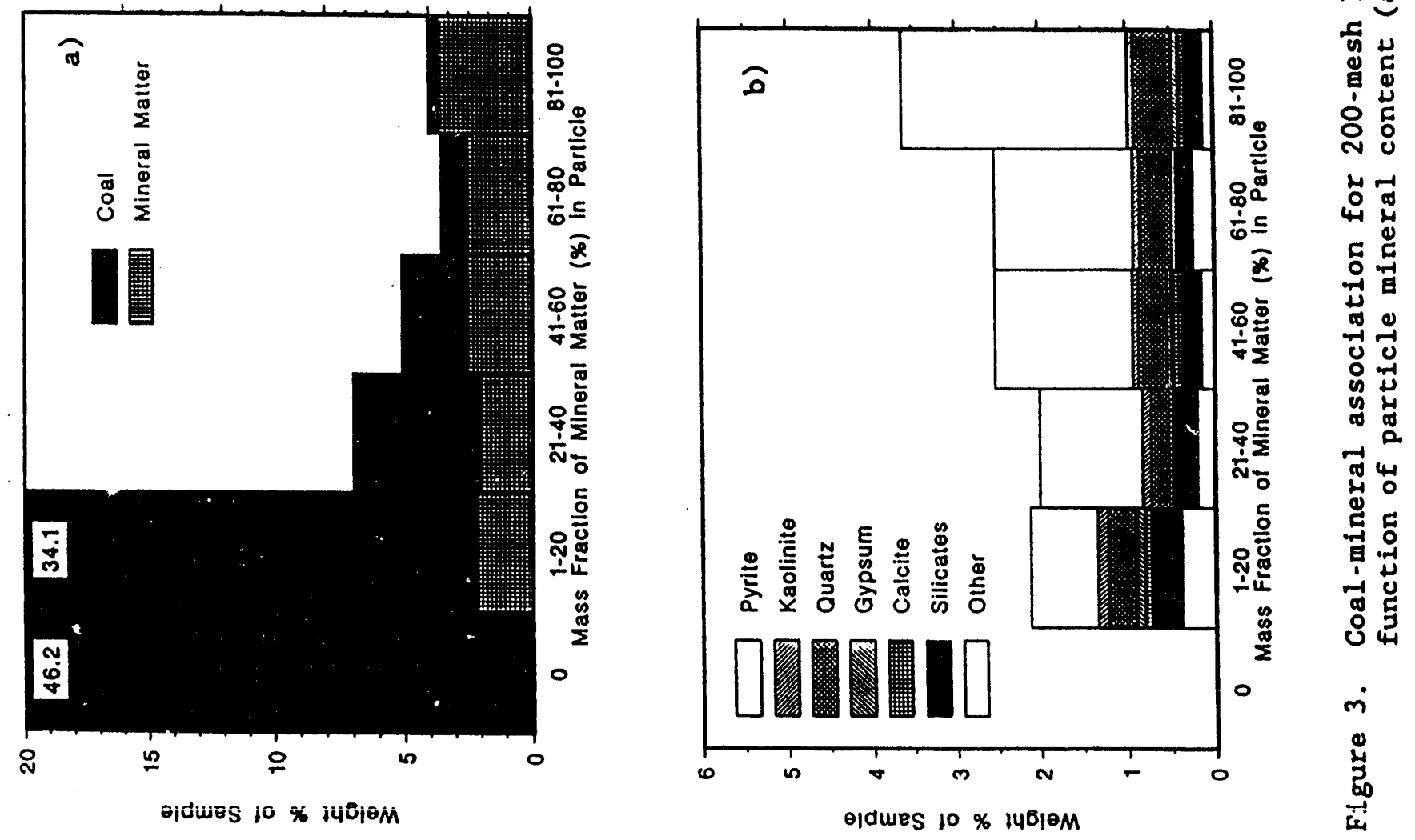

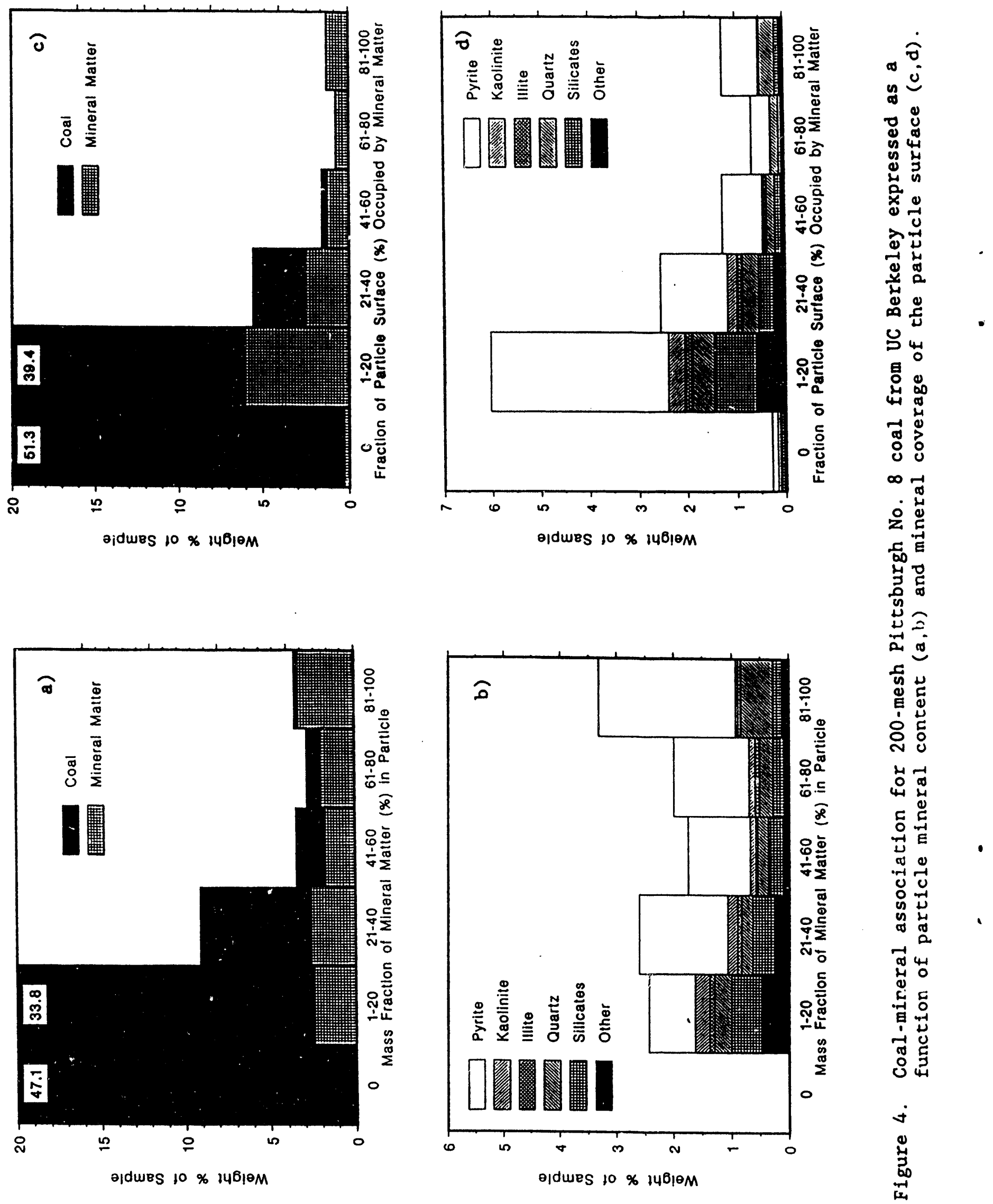

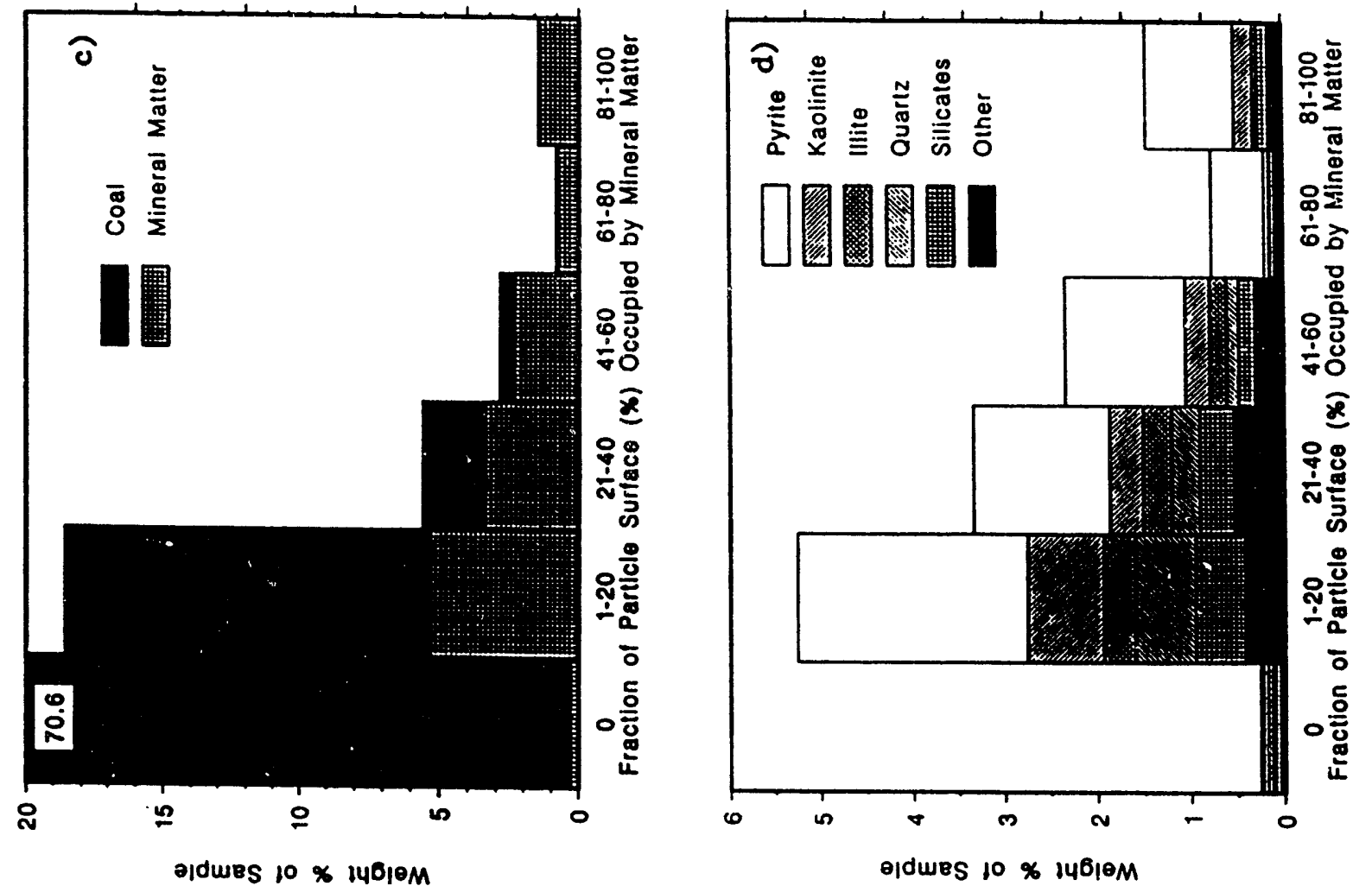

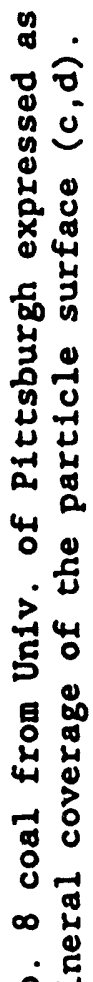

之를

恖它

공

战。 出
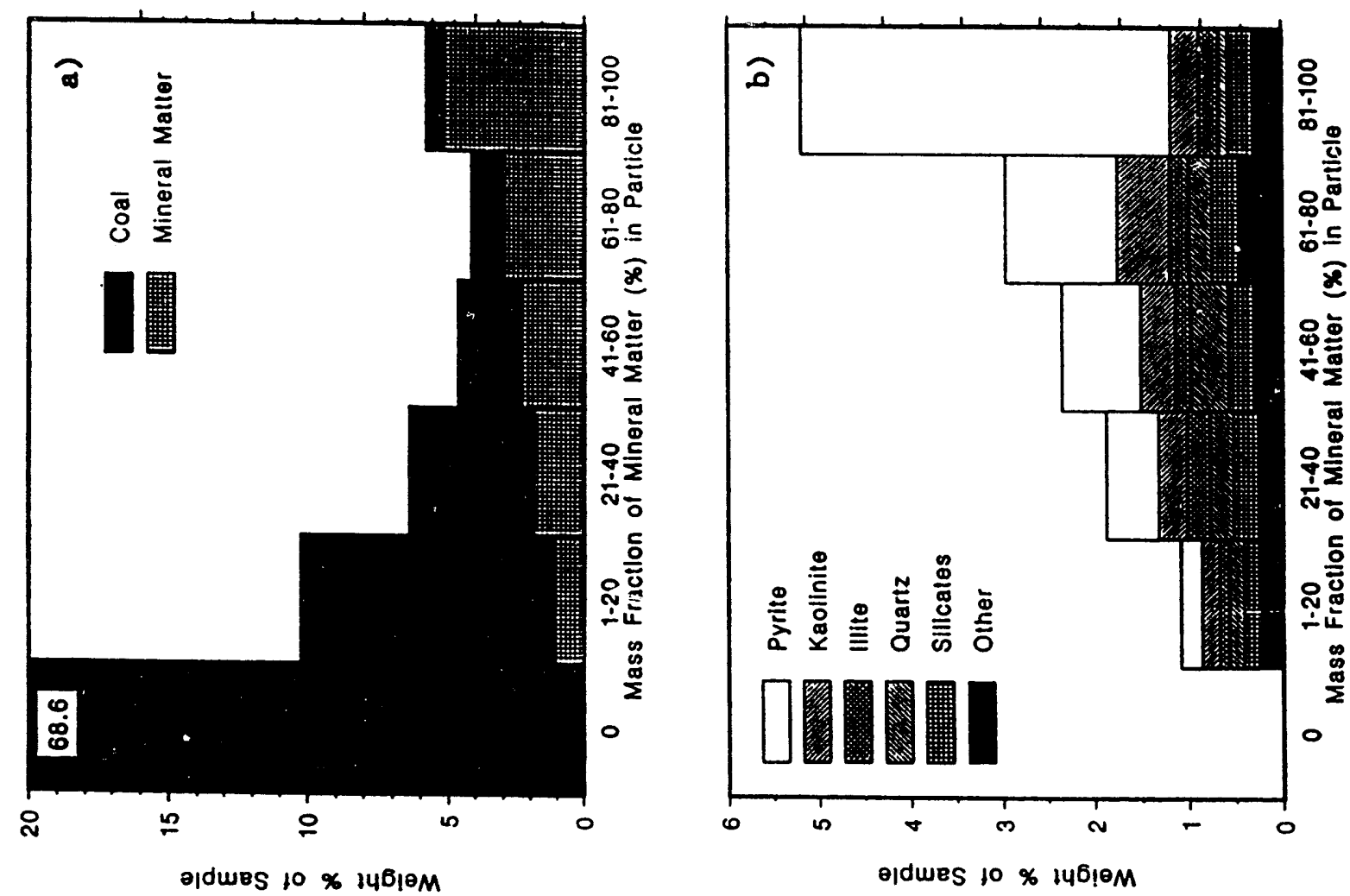

c5

ป 님

ㅇํㅇ

응

เै

4

등

本

更

o

(2)

- 4

幽

मै :

击出

ने

ठำ

盛 
UP (Figure 5a). A relatively larger fraction of the mineral matter is found in particles of high mineral content. Liberation is next best in the samples of Upper Freeport, Illinois No. 6 and Pittsburgh No. 8 coals from UCB, in that order. Much of the greater liberation observed in the sample from UP appears to be due to the smaller overall particle size of this sample compared to the samples from UCB. However, the extra cost of producing and handling these finer particles must be considered in determining which grinding process is most economical as well as effective in liberating mineral matter.

For all three coals, there is some preferential liberation of pyrite (see section $b$ ) as might be expected from the coarse nature of much of the pyrite noted above. It appears that quartz may be somewhat preferentially liberated for the three coals from UCB, but the preferential liberation is not so apparent for quartz in the Pittsburgh No. 8 sample from UP. Little other preferential liberation or association of the mineral matter with regard to coal is noted.

For all three coals, coal-mineral association is greater when expressed in terms of the mineral coverage of the particle surface. Even the mineralrich particles appear to have a significant amount of their surface covered by the coal that is present in those particles. Little indication of preferential association or liberation of one mineral over another was found.

The distribution of mineral matter across these figures is very similar among all four samples. However, it may be noted that the Pittsburgh No. 8 sample from UP does show less coal associated with the mineral matter in the $1-20 \%$ range of Figure $5 \mathrm{c}$. Thus, it appears that coal recovery will be greater for this sample for a given level of mineral removal.

To aid the comparison of the cleanability of these coals, predicted coal recovery versus mineral rejection was calculated from the data of Figures 2-5. For several grades of coal across the bottom axes of these figures, the amount and quality of coal to the left of each point (i.e., representing particles of higher grade) was calculated and compared with the amount of coal and mineral matter in the original sample to predict coal recovery and mineral rejection. These results are shown in Figures 6a-6d. For example, a process which collects particles of less than $20 \%$ mineral matter content from the Upper Freeport coal (Figures 2a-b) would collect 
88.9\% of the organic matter in the original sample and would reduce the pyrite content by $91.5 \%$ and the total mineral matter content by $81.7 \%$ from what they were in the original sample. These calculations, performed on the basis of both particle mineral content for density-based cleaning processes and mineral coverage of the particle surface for surface-based cleaning processes, were repeated for many points wlong the bottom axes of Figures 25 to predict the relationship between coal recovery and mineral rejection for a cleaning process.

The curves of Figure 6 reveal significant differences in the cleanabilities of these four samples. The two ends of the curves are especially helpful in determining cleanability. At high coal recoveries, 1.e., the left end of the curves, the mineral rejection level at which the curves begin dropping from $100 \%$ coal recovery (e.g., $99 \%$ recovery) indicate the amount of well-1iberated mineral matter. At the other extreme, the amount of mineral rejection at coal recoveries of $70-80 \%$ indicates the iimiting cleanability of a sample. For all three coals and for either density- or surface-based cleaning methods, about $30 \%$ of the mineral matter appears to be removable with practically no loss of organic material. However, at higher mineral rejections, several differences in coal-mineral association are reflected in the predicted recovery-rejection curves. In this region, predicted density-based cleanability is clearly best for the Pittsburgh No. 8 sample from UP. Of the three coals from UCB, cleanability is best for the sample of Upper Freeport coal, followed by the Illinois and Pittsburgh No. 8 samples. The same ranking also holds for predicted surface-based cleanability, although the Illinois No. 6 and Pittsburgh No. 8 samples from UCB are very similar in this comparison.

\section{CONCLUSIONS}

The association of coal and mineral matter has been measured using SEMAIA for four 200-mesh samples of coal used in the DOE-sponsored development of surface-based cleaning processes. SEM-AIA results have also been used to predict cleanability for density-based and surface-based processes. Cleanability was found to be best for a sample of Pittsburgh No. 8 coal received from the UP, primarily due to its fine particle size. For samples received from UCB, cleanability was predicted to be best for Upper Freeport côal, followied by Illi.ıois No. 6 and then Pittsburgh No. 8 coals. 


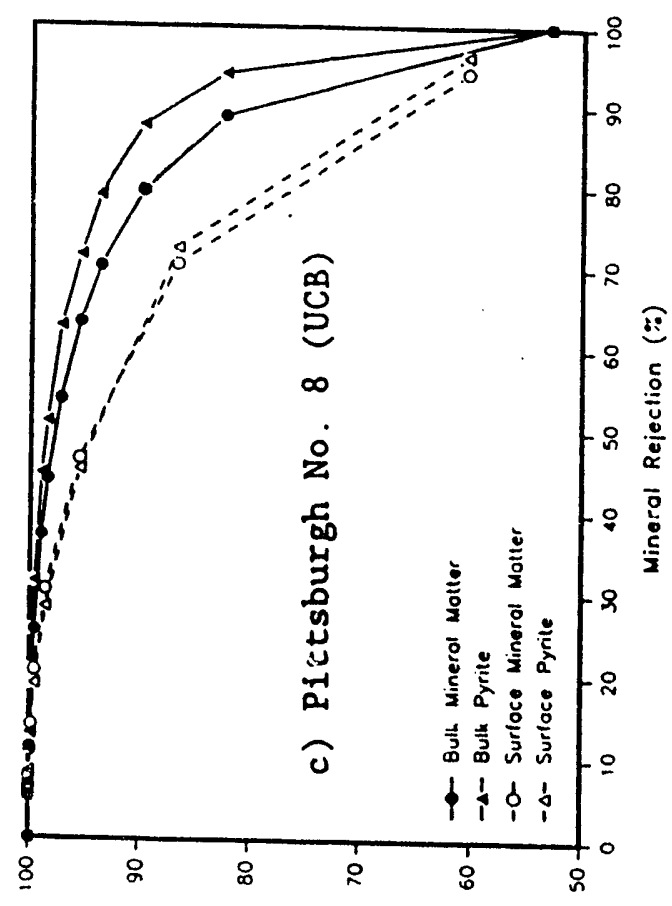

(\%) Nonosey 1000

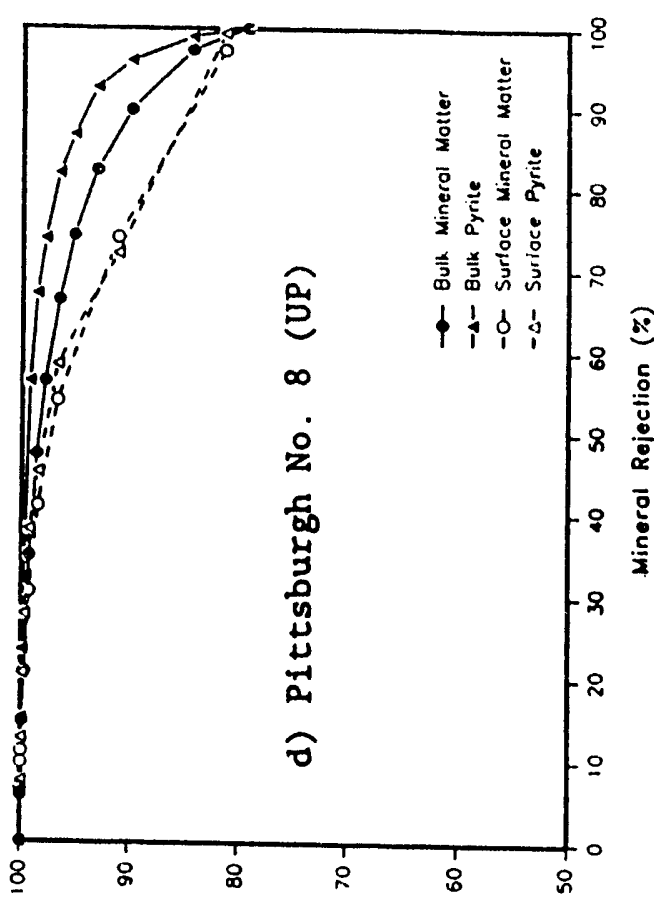

(x) Nenosey 1000

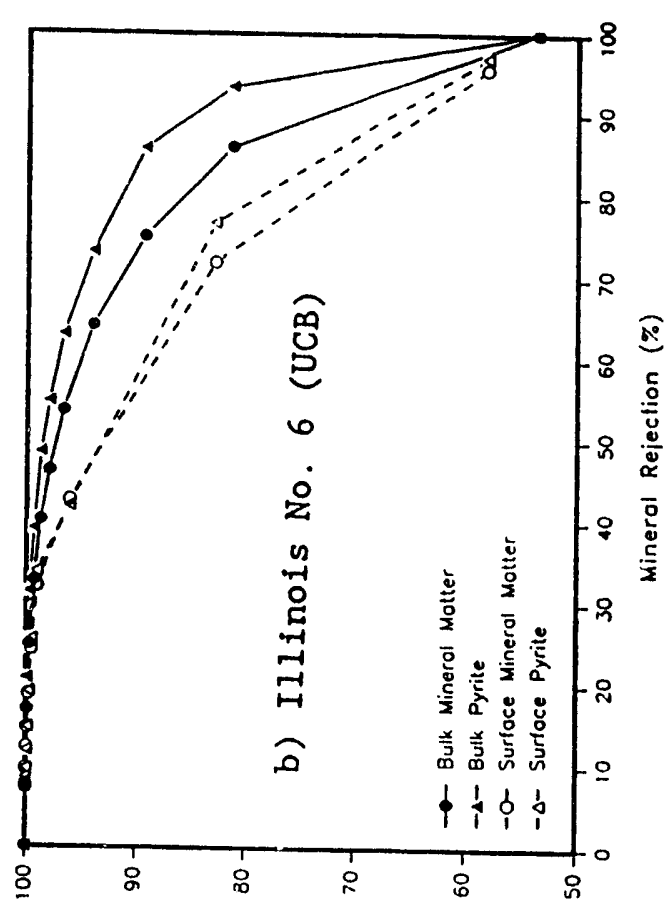

(\%) 1sanojay 1000

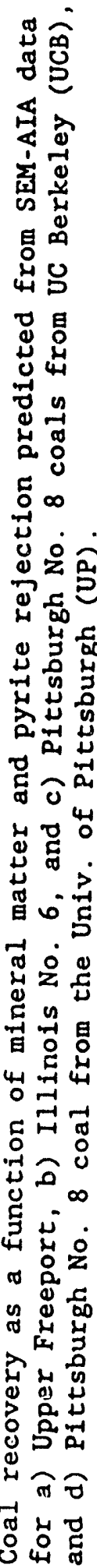

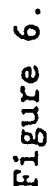


These predictions are based on SEM-AIA measurements of coal-mineral association only. Such association plays a very fundamental role in determining a coal's cleanability. Of course there are other significant factors such as the chemical rature, e.g., the oxidation state, of the coal surface. However, just as a coal cannot be cleaned by surface-based techniques if its surface is not sufficiently hydrophobic to accept an air bubble or oil droplet, neither can a coal be cleaned if the mineral matter is still physically associated with the coal.

Further analyses are necessary to validate these preliminary AIA results.

\section{ACKNOWLEDGMENT}

We would like to thank Dr. Yisen Cheng at the University of Pittsburgh and $\mathrm{Dr}$. James Hanson at University of California at Berkeley for providing samples of the three coals used in their work.

\section{REFERENCES}

1) W.E. Straszheim and R. Markuszewski, "Association of Mineral Matter with the Organic Coal Matrix", Am. Chem. Soc. Div, of Fuel Chem. Preprints, 34(3), 648-655 (1989).

2) W.E. Straszheim and R. Markuszewski, "Evaluation of Physical Coal Beneficiation Using Computerized Microscopy", Process Mineralogy IX, W. Petruk, et al. (eds.), The Metallurgical Society of AIME, (1989), (in preparation).

3) P.H. Given and R.F. Yarzab, "Analysis of the Organic Substance of Coals: Problems Posed by the Presence of Mineral Matter", In Analytical Methods for Coal and Coal Products, Vol. II, C. Karr, Jr., ed., Academic Press, New York, 1978, pp. 3-41.

4) W.E. Straszheim, K.A. Younkin, R.T. Greer, and R. Markuszewski, "Mounting Materials for SEM-based Automated Image Analysis of Coals", Scanning Microscopy, 2(3), 1257-1264 (1988). 


\section{DISTRIBUTION LIST}

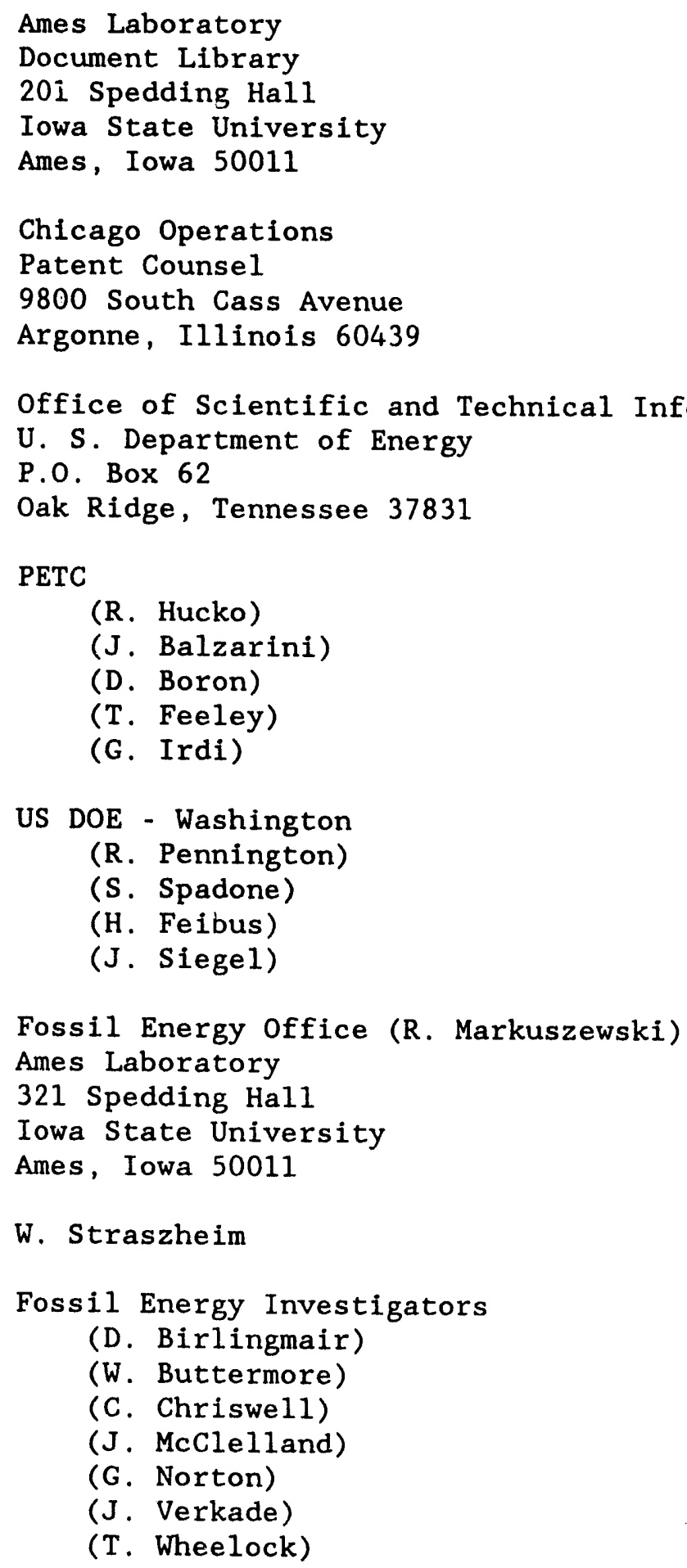

Fossil Energy Office (R. Markuszewski)

Ames Laboratory

321 Spedding Hall

Iowa State University

Ames, Iowa 50011

W. Straszheim 

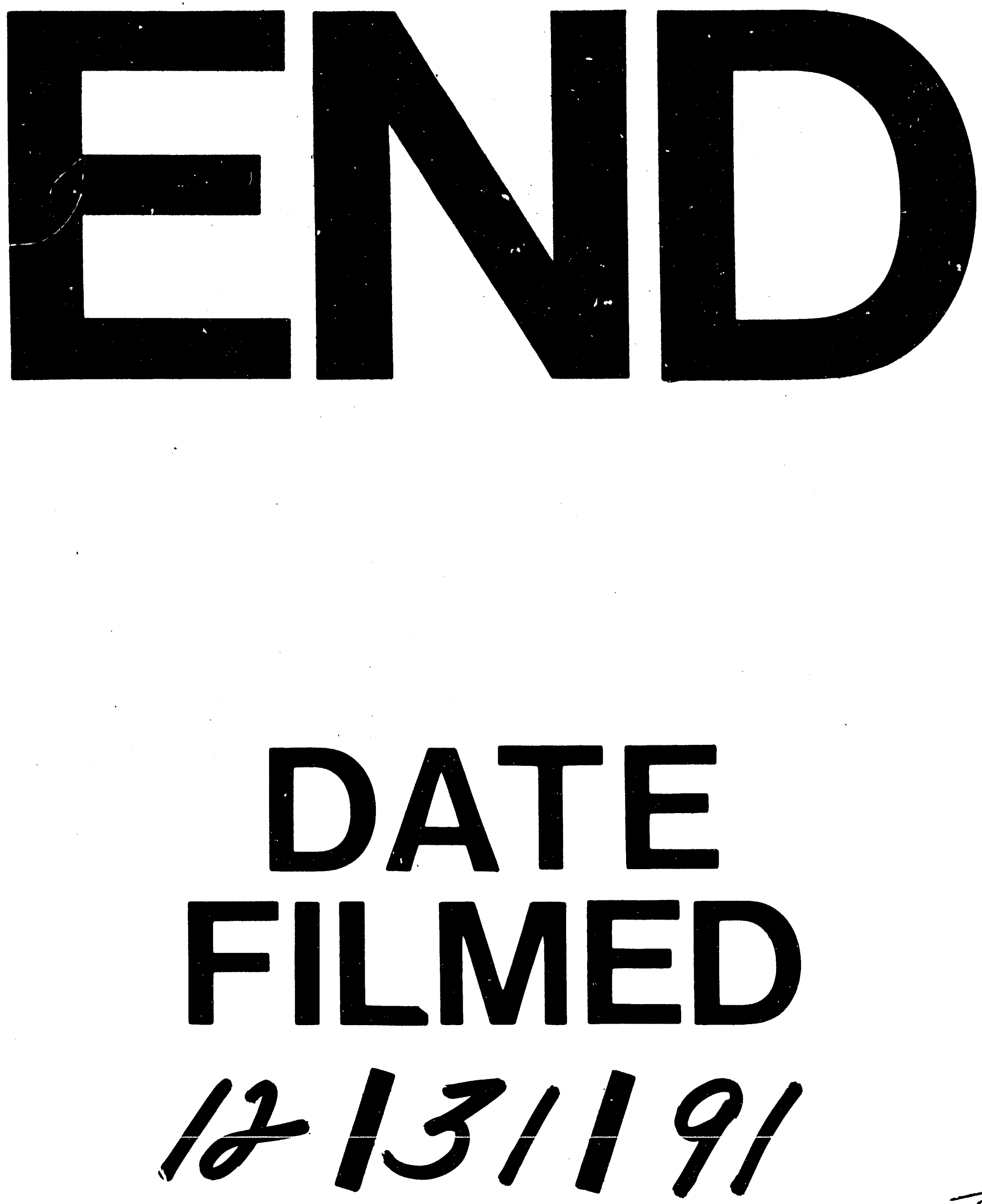
.

. 